\title{
Induction of larval settlement and metamorphosis by pharmacological and conspecific associated compounds in the serpulid polychaete Hydroides elegans
}

\author{
Patrick J. Bryan, Pei-Yuan Qian*, Jennifer L. Kreider, Fu-Shiang Chia \\ Department of Biology, Hong Kong University of Science and Technology, Clearwater Bay, Kowloon, Hong Kong
}

\begin{abstract}
Field populations of the serpulid polychaete Hydroides elegans occur in dense aggregations. Preliminary laboratory assays showed that planktonic larvae $H$. elegans from Hong Kong waters did not settle and metamorphose without proper chemical cues and could remain planktonic up to $14 \mathrm{~d}$ in laboratory culture. Adult $H$. elegans capture conspecific larvae with feeding tentacles but cannot readily consume older, competent larvae. Contact between adult feeding tentacles and larvae may increase larval exposure to adult associated inductive compounds. In this study, we tested the effects of homogenates of adult worms and their tubes, as well as a variety of artificial inducers, on settlement and metamorphosis of $H$. elegans larvae. Conspecific adult homogenates induced 39 and $82 \%$ of larvae to settle and metamorphose within a period of 2 and $4 d$, respectively. Homogenates of the adult tube alone did not induce settlement, indicating that the inducer originates from the worm. Extraction and assays on crushed adult homogenates revealed that the inductive compounds from adults are smaller than 10000 daltons and can be bound to amberlite XAD-7. Further isolation and identification of the conspecific associated inducer will enable studies of chemoreceptors and signaling pathways involved in metamorphosis. Additionally, among 5 artificial inducers tested, isobutyl methylxanthine (IBMX) induced a high percentage of normal metamorphosis while gamma-aminobutyric acid (GABA), choline chloride, dihydroxyphenyl L-alanine (L-DOPA), and potassium chloride evoked a low percentage of settlement, but abnormal metamorphosis. Ammonia had no effect on the metamorphosis of $H$. elegans.
\end{abstract}

KEY WORDS: Chemical cues · Gregariousness - Larval metamorphosis - Hydroides elegans · Conspecific cue

\section{INTRODUCTION}

Larvae of many marine invertebrates are attracted to prey or conspecifics as sites for settlement and metamorphosis (reviewed by Pawlik 1992, Rodriguez et al. 1993). The location of a site inhabited by conspecific adults could possess both positive and negative characteristics. Sessile organisms must live within close proximity to conspecifics to maximize reproductive success. However, competition for space and food can result if the community is too crowded.

\footnotetext{
- Addressee for correspondence.

E-mail: boqianpy@usthk.ust.hk
}

Biochemical processes for mediating larval settlement and metamorphosis have been studied intensively in recent years (reviewed by Morse 1990, Pawlik 1992). Cues which induce metamorphosis have been found to originate from living conspecifics, prey items, biofilms, and predators (reviewed by Pawlik 1992, Rodriguez et al. 1993). An alternative research area of larval settlement bypasses study of the external chemoreceptors and natural cues, and directly stimulates internal pathways with compounds that act on the larval nervous system or affect membrane permeability. Such compounds include GABA (gamma-aminobutyric acid) (Morse \& Morse 1984, Morse 1990), choline and choline precursors (Hirata \& Hadfield 1986, Hadfield \& Pennington 1990), L-DOPA (dihydroxyphenyl L-alanine) and related com- 
pounds (Coon et al. 1985, Weiner et al. 1985), ions such as $\mathrm{K}^{+}, \mathrm{Cs}^{+}$, and $\mathrm{Rb}^{+}$(Baloun \& Morse 1984, Rittschof et al. 1986. Pechenik \& Heyman 1987), and c-AMP (cyclic adenosine monophosphate) affecting compounds (Rittschof et al. 1986, Jensen \& Morse 1990, Pawlik 1990. Clare et al. 1994). Pharmacological approaches have been valuable for determining competence of larvae (Pechenik et al. 1995). It is clear that these compounds do not act on external chemoreceptors (Baloun \& Morse 1984, Hirata \& Hadfield 1986) and that they do not compete with natural settlement cues (Hirata \& Hadfield 1986). Therefore, pharmacological approaches and use of natural settlement cues can accomplish separate objectives. For instance, pharmacological approaches can determine age of competence. Studies of natural compounds released into the environment, which induce metamorphosis, can be used to probe pathways involving chemoreceptors.

Hydroides clcgans is a gregarious tube building polychaete which occurs in tropical and sub-tropical waters. This species has been observed to display different behaviors throughout its distribution. For example, larvae of $H$. elegans populations near India undergo metamorphosis when competent, regardless of the presence of external cues (Sr. Mary pers. comm.). However, larvae of $H$. elegans from Hawaii do not settle until provided with an appropriate environmental cue (Hadfield et al. 1994); the larvae settle on aged biofilms preferentially over unfilmed surfaces (Hadfield et al. 1994). Settlement behavior on biofilms has also been demonstrated for other species of invertebrates (Kirchman et al. 1982, Fitt et al. 1990) including the congeneric Hydroides dianthus (Toonen \& Pawlik 1994). The ability of $H$. elegans larvae, from Hong Kong waters, to remain in the larval state until stimulated by specific cues makes them ideal for the study of chemically mediated settlement and metamorphosis. It is important to establish the behavioral and physiological responses of $H$. elegans from Hong Kong to determine if it is unique or similar to other populations and congeneric species.

This study evaluates the effects of artificial inducers and compounds associated with conspecifics on larval settlement and metamorphosis of the polychaete $\mathrm{Hy}$ droides elegans. Particularly, we addressed the following questions: (1) do larval densities affect larval metamorphosis, (2) are larvae of $H$. elegans induced to metamorphose by compounds originating from conspecifics, and (3) what effects do artificial inducers have on $H$. elegans metamorphosis.

\section{MATERIALS AND METHODS}

Larval culture. Adult Hydroides elegans were collected from a submerged raft of a fish farm in Port
Shelter, Hong Kong $\left(22^{\circ} 19^{\prime} \mathrm{N}, 114^{\circ} 16^{\prime} \mathrm{W}\right)$. Larval rearing procedures were modeled after Hadfield et al. (1994). H. elegans has separate sexes. Individual worms were placed in sterile petri dishes (diameter: $10 \mathrm{~cm}$ ) containing $20 \mathrm{ml}$ of $0.22 \mu \mathrm{m}$ filtered seawater (FSW). Tubes of adult $H$. elegans were gently broken and observed for the release of gametes, which occurred after a few minutes. Eggs were pink in color and sperm milky white. Eggs of 2 or 3 different females were combined in 1 dish and a dilute sperm solution from 1 or 2 males was added and the dishes were agitated. Eggs were viewed after $30 \mathrm{~min}$ and the percent of fertilized and developing embryos was determined from a sub-sample. During all fertilizations performed, greater than $95 \%$ of eggs were fertilized and developing. After viewing fertilized eggs, excess sperm was removed by filtration and the eggs were transferred to a 4 I Nalgene beaker containing FSW. Larvae were fed Isochrysis gaibana (Tahitian strain) at a concentration of approximately $1 \times 10^{5}$ cells $\mathrm{ml}^{-1}$ for 6 to $7 \mathrm{~d}$ until they reached a competent state to settle and metamorphose. Competence was determined by larval morphology which is similar for $H$. elegans and $H$. dianthus (Wisely 1958, Scheltema et al. 1981). Competent larvae possessed elongated tails and the ciliary ring became reduced and migrated close to the head. Cultures were maintained at $24^{\circ} \mathrm{C}$ under a $15: 9 \mathrm{~h}$ light:dark photoperiod. Culture chambers were aerated by placing a line of tubing from an electric pump and controlling the flow through a glass pipette with a valve at a rate of 2 bubbles $\mathrm{s}^{-1}$. Larvae were fed every $2 \mathrm{~d}$. Water was changed on Days 3 and 5 of the larval culture period

Settlement experiments were performed on larvae that were 6 to $7 \mathrm{~d}$ post-fertilization. Assays were conducted in Falcon 1006 petri dishes (diameter: $5 \mathrm{~cm}$, height: $0.9 \mathrm{~cm}$ ). Approximately 20 larvae were placed in each petri dish, containing $5 \mathrm{ml}$ of FSW, and incubated at $24^{\circ} \mathrm{C}$ on a $15: 9 \mathrm{~h}$ light:dark photoperiod. The status of larvae in experimental dishes was determined under a dissecting microscope at 2 and 4 d after initiation of an assay, unless otherwise noted. In all the experiments, the control contained filtered seawater only as the testing medium unless otherwise specified. Larvae that had attached to the dish, produced a tube, and grown tentacles were considered to have undergone normal metamorphosis. Unattached and swimming or crawling larvae were considered to be unmetamorphosed. Several types of abnormal metamorphosis were classified as: (1) attached, production of tentacles, but no tube; (2) not attached, production of tentacles, but no tube; and (3) deformed development involving elongation of larvae and crawling behavior, but no tube or tentacle production. Photos were taken of normal and abnormally metamorphosed larvae for future reference. Experiments generally consisted of 
5 or 6 replicates of each treatment or control except where otherwise noted. Larvae were not fed and water was not changed during the duration of experiments.

Effect of larval density on settlement behavior. The effect of larval density on settlement behavior and metamorphosis was determined by addition of 10,20 , $40,60,80$, and 100 larvae to petri dishes containing $5 \mathrm{ml}$ of FSW. The dishes were incubated under the same conditions as described above. Numbers of metamorphosed larvae were determined 2, 4, and $6 \mathrm{~d}$ after the initiation of the experiment. This assay was performed to determine if larval interaction can influence metamorphosis in petri dishes and to establish an optimal number of larvae per dish for larval metamorphosis assays.

Worm homogenates. Adult homogenates were assayed at several concentrations to evaluate the effect on larval settlement and metamorphosis. Adult worms in tubes were gently scrubbed with a brush and paper towels to remove any dirt and algae contaminating the tube. Worms were dipped in FSW then blotted dry on a paper towel and weighed to the nearest $0.001 \mathrm{~g}$. Homogenates were prepared by crushing and sonicating the adults in deionized water at a ratio of $0.1 \mathrm{~g}$ worm $\mathrm{ml}^{-1}$ water. The homogenate was centrifuged at $13000 \mathrm{rpm}(13000 \times \mathrm{g})$ for $10 \mathrm{~min}$. The supernatant was dried under nitrogen then resolubilized in 80:20 methanol:ethanol. Precipitated salts were weighed and found to compose a negligible portion of the original homogenate. The methanol: ethanol soluble homogenate was dried under nitrogen and weighed. The dry homogenate was stored at $-20^{\circ} \mathrm{C}$ until use. Homogenate was assayed at concentrations of $1.4,0.6,0.2,0.1$, and $0.04 \mathrm{mg} \mathrm{ml}^{-1}$ seawater. Numbers of metamorphosed larvae were determined 2, 4, and $6 \mathrm{~d}$ after the initiation of the experiment. After initial assay of the worm and tube homogenate, homogenates were prepared using similar procedures for the worm alone (removed from the tube), tube alone, and tube alone baked in a muffle furnace at $500^{\circ} \mathrm{C}$ (to remove all organics). These homogenates were assayed for 2,4 , and $6 \mathrm{~d}$ along with the worm and tube homogenate at similar concentrations. A duplicate assay of worm and tube homogenate was conducted at concentrations of $0.2,0.1$, and $0.04 \mathrm{mg}$ homogenate $\mathrm{ml}^{-1}$ seawater.

The adult and tube homogenate was size fractionated using ultracentrifugation at $4000 \times g$ for $1 \mathrm{~h}$ at $4^{\circ} \mathrm{C}$. Three fractions $(<10000 \mathrm{MW},>10000$ but $<30000 \mathrm{MW}$. and $>30000 \mathrm{MW}$ ) were collected and stored in aqueous solution at $-20^{\circ} \mathrm{C}$ until testing. Fractions were assayed at concentrations equivalent to those tested for the unfractionated homogenate with the exception of the highest concentration (i.e. $0.6,0.2,0.1$, and $0.04 \mathrm{mg}$ $\mathrm{ml}^{-1}$ seawater).
Individual larval response to homogenate size fraction. Larvae were placed individually in wells of 24-well Corning dishes containing $1 \mathrm{ml}$ of FSW per well. Each well contained approximately $0.2 \mathrm{mg}$ of the $<10 \mathrm{~K} \mathrm{MW}$ fraction of adult and tube homogenate. Control wells contained $1 \mathrm{ml}$ of FSW alone. Three dishes of 24 wells for the treatment and 3 dishes for the control were utilized in the experiment (i.e. 72 individuals for control and treatment). The percent larval settlement was determined $4 \mathrm{~d}$ after initiation of the assay.

Separation utilizing amberlite $\mathrm{XAD}$ resin. The $<10 \mathrm{~K}$ MW fraction was further separated utilizing XAD resins. The size fraction was passed through a column containing XAD-2 resin, which binds lipophilic compounds from water, and washed with several volumes of water. Columns were washed repeatedly with water and methanol to prepare them for fractionating the homogenate size fraction. After loading the size fraction on the column, it was then washed with 2 volumes of methanol and the elutant collected. The procedure was repeated with the water washing being passed through XAD-7 resin, which binds peptides from water (Quinn 1988). The compounds and salts in the wash water were combined and all fractions were dried under nitrogen. The water that was passed through both XAD-2 and XAD7 (Thru XAD) was combined and dried down for assay to represent compounds that were not bound to either type of resin. These fractions were re-solubilized in seawater at a concentration of $0.2 \mathrm{mg} \mathrm{ml}^{1}$ and assayed for induction of metamorphosis with $\mathrm{Hy}$ droides elegans larvae. Before loading the size fraction onto the columns, methanol washings of both XAD-2 and XAD-7 were collected and dried down. A residue remained after drying the washing of XAD-7 and was assayed as an XAD control. No residue was present in the XAD-2 methanol washing. An unseparated $<10 \mathrm{~K}$ MW fraction was also assayed to account for the effects of the separation process on the active compounds

Pharmacological inducers. $\mathrm{KCl}$, GABA (gammaaminobutyric acid), choline, L-DOPA (dihydroxyphenyl L-alanine), and IBMX (isobutyl methylxanthine), known pharmacological inducers of larval marine invertebrate metamorphosis, were assayed for their effects on the larval settlement and metamorphosis of Hydroides elegans. $\mathrm{KCl}$ was assayed at concentrations of $10,20,30$, and $40 \mathrm{mM}$ above normal seawater levels. Solutions were prepared by adding an appropriate amount of a $40 \mathrm{mM}$ elevated stock solution (in seawater) to the corresponding volume of FSW to attain the desired concentration. GABA was assayed at concentrations of $10^{-3}, 10^{-4}, 10^{-5}$, and $10^{-6} \mathrm{M}$ in seawater. Solutions were prepared by serial dilutions of a 
$10^{-2} \mathrm{M}$ stock solution with FSW. Choline, used as choline chloride, was assayed at concentrations of $10^{-2}$, $10^{-3}, 10^{-4}$, and $10^{-5} \mathrm{M}$. Solutions were prepared the same as described above. L-DOPA was assayed by adding larvae to a fresh solution of L-DOPA in seawater and allowing continuous exposure of the larvae. L-DOPA was tested at $10^{-3}, 10^{-4}, 10^{-5}$, and $10^{-6} \mathrm{M}$. IBMX was assayed at concentrations of $10^{-3}, 10^{-4}, 10^{-5}$, and $10^{-6} \mathrm{M}$. Coon et al. (1990b) found ammonia to affect the settlement of oyster larvae. Since crushed conspecifics of $H$. elegans may release ammonia, ammonium chloride was assayed for induction of settlement and metamorphosis at concentrations of $10^{-2}$, $10^{-3}, 10^{-4}, 10^{-5}, 10^{-6}$, and $10^{-7} \mathrm{M}$ (Coon et al. 1990b).

Statistical analyses. The proportion of metamorphosed larvae data was arcsine-transformed before statistical analysis was carried out. This transformation served the role of normalizing the data and reducing heteroscedasicity, which was determined utilizing a Cochran's test $(\alpha=0.01)$. In some replicates, no larvae metamorphosed. These replicates were given a value of $1 / 4 \mathrm{n}$ to improve arcsine transformation (Bartlett 1937). One hundred percent metamorphosis did not occur in any assay. One-way ANOVAs were utilized with Tukey's multiple comparisons tests $(\alpha=0.05)$ to analyze the data from each time interval. The data presented in all figures is untransformed.

\section{RESULTS}

\section{Effect of larval density on settlement behavior}

The number of larvae added to a $5 \mathrm{ml}$ petri dish affected percent metamorphosis (Fig. 1). After a $2 \mathrm{~d}$ incubation, low levels of metamorphosis were observed at densities of 60,80 , and 100 larvae per $5 \mathrm{ml}$ dish. In the dishes with 100 larvae, 5 and $35 \%$ of larvae had metamorphosed after 4 and 6 d, respectively. Fewer larvae metamorphosed in dishes with 40,60, and 80 larvae. No larvae metamorphosed in dishes containing 10 and 20 larvae even after 6 d. Dishes containing 100 larvae displayed a significantly higher level of metamorphosis ( $p<0.05$. Tukey's test) than dishes containing $10,20,40,60$, and 80 larvae after $4 \mathrm{~d}$. After a $6 \mathrm{~d}$ incubation, metamorphosis in dishes containing 100 larvae was statistically higher ( $\mathrm{p}<0.05$, Tukey's test) than those containing $10,20,40$, and 60 larvae, however, there was not a significant difference between 100 and 80 larvae per dish ( $p>0.05$, Tukey's test).

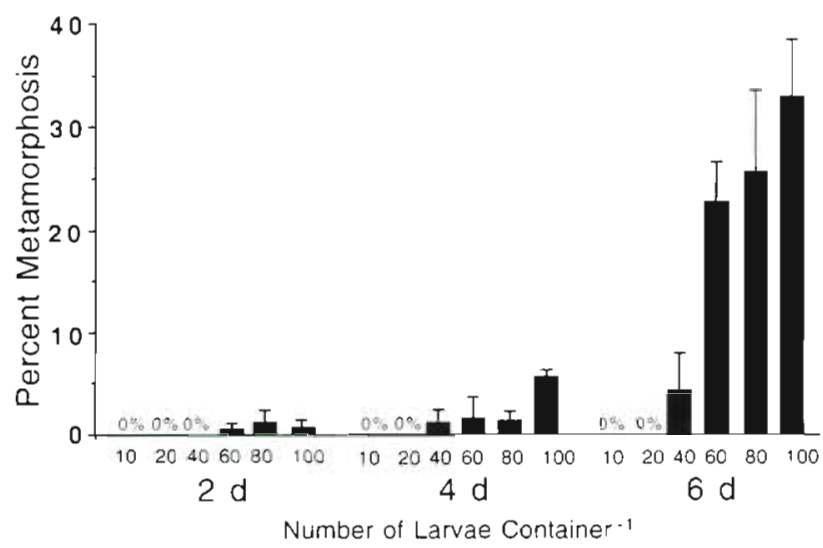

Fig. 1 Hydroides elegans. Effect of larval density on percent larval metamorphosis of worms after 2,4 , and $6 \mathrm{~d}$ incubations.

Data plotted are mean \pm standard deviation of 6 replicates

\section{Worm homogenates}

Water homogenates of adult worms in tubes, worms alone, tubes alone, and worm tubes baked in a muffle furnace were assayed at similar concentrations for metamorphic induction of Hydroides elegans larvae (Fig. 2). No larvae metamorphosed in the control after a 4 d incubation. Homogenized worm with tube induced $68 \%$ metamorphosis at a concentration of $0.2 \mathrm{mg}$ homogenate $\mathrm{ml}^{-1}$ seawater. Tube alone and baked tube induced 2 and $0 \%$ metamorphosis, respectively, at a concentration of $0.2 \mathrm{mg}$ homogenate $\mathrm{ml}^{-1}$ seawater. The worm alone homogenate induced a

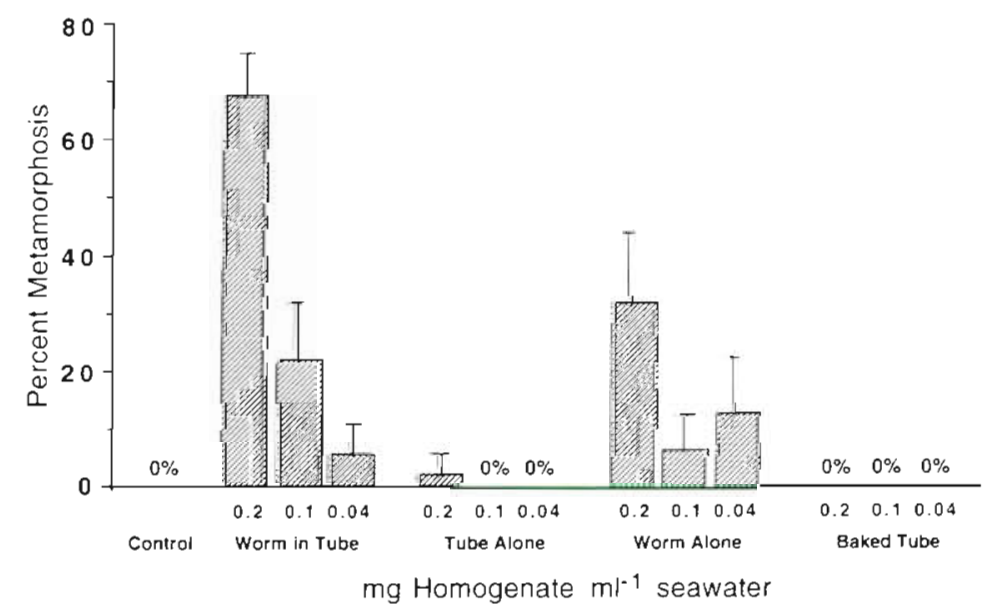

Fig. 2. Hydroides elegans. Activity of various concentrations of conspecific homogenates (worm and tube, tube alone, worm alone, and baked tube) on percent larval metamorphosis of worms after a 4 d incubation. Control is filtered seawater (FSW). Data plotted are mean \pm standard deviation of 6 replicates 


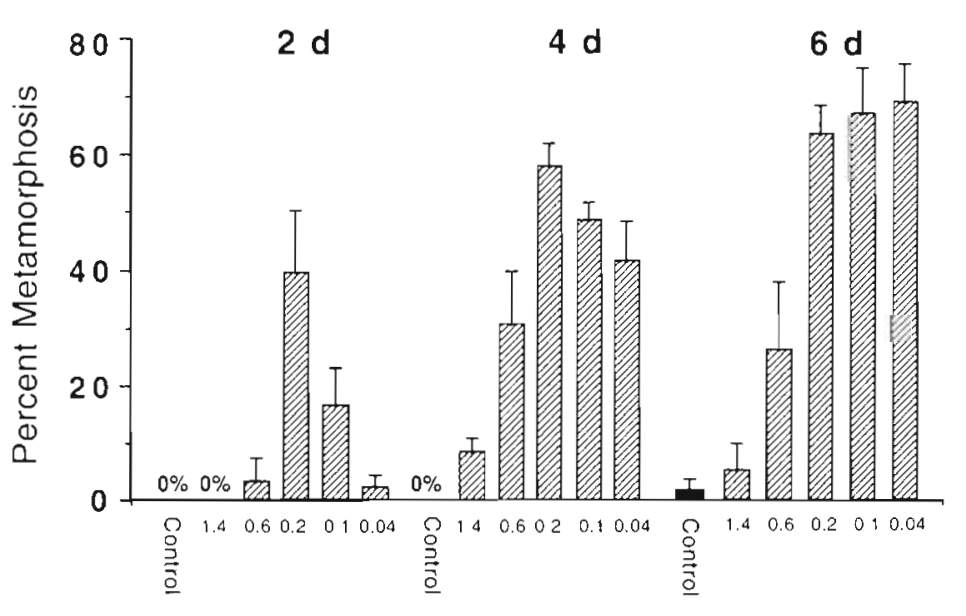

mg Homogenate $\mathrm{ml}^{-1}$ seawater

Fig. 3. Hydroides elegans. Percent larval metamorphosis of worms in response to conspecific worm homogenate assayed at 5 concentrations after 2, 4, and 6 d incubations. Control is filtered seawater (FSW). Data plotted are mean \pm standard deviation of 5 replicates

lower percent metamorphosis than the homogenate of a combination of worm and tube.

Adult worm in tube homogenate was assayed at 5 concentrations to determine the concentration effect on larval metamorphosis (Fig. 3). The percentages of worms metamorphosed in dishes containing concentrations of $0.6,0.2,0.1$, and $0.04 \mathrm{mg}$ homogenate $\mathrm{ml}^{-1}$ seawater were all significantly higher than the control dishes (FSW only) $(\mathrm{p}<0.05$, Tukey's test). The concentration of $0.2 \mathrm{mg}$ homogenate $\mathrm{ml}^{-1}$ seawater induced the highest levels of metamorphosis after a 2 and $4 \mathrm{~d}$ incubation ( $p<0.05$, Tukey's test). At Day 6 , there was

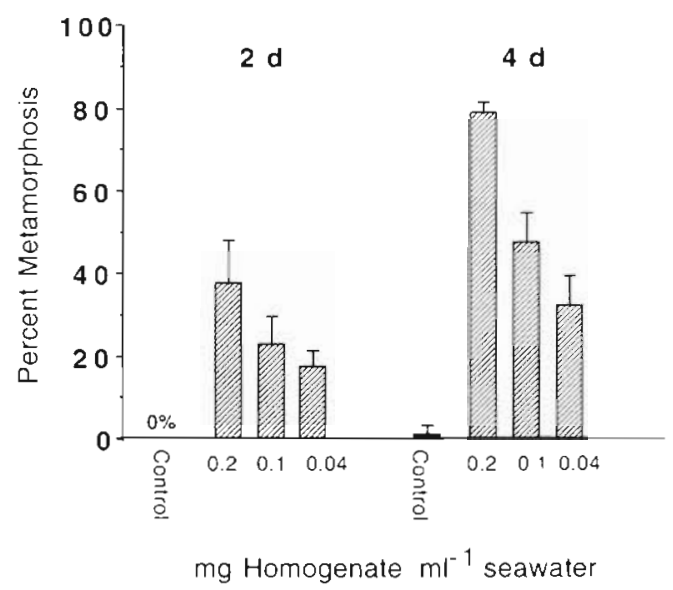

Fig. 4. Hydroides elegans. Effect of of various concentrations of conspecific homogenate on percent larval metamorphosis of worms (duplicate assay) concentrations after 2 and $4 \mathrm{~d}$ incubations. Control is filtered seawater (FSW). Data plotted are mean \pm standard deviation of 5 replicates no significant difference among $0.2,0.1$, and $0.04 \mathrm{mg}$ homogenate $\mathrm{ml}^{-1}$ seawater $(\mathrm{p}<0.05$, Tukey's test). The highest concentrations assayed, 1.4 and $0.6 \mathrm{mg} \mathrm{ml}^{-1}$, were toxic to larvae (Fig. 3). In a duplicate assay, homogenate at a concentration of $0.2 \mathrm{mg} \mathrm{ml}^{-1}$ seawater induced $82 \%$ metamorphosis after $4 \mathrm{~d}$ (Fig. 4 ) while only about $3 \%$ of larvae metamorphosed in the control within $4 \mathrm{~d}$.

\section{Larval response to homogenate size fractions}

Size fractions of $<10,10-30$, and $>30 \mathrm{~K} \mathrm{MW}$ were assayed along with unfractionated worm homogenate (UWH) (Fig. 5). The $<10 \mathrm{~K}$ MW fraction induced the highest levels of metamorphosis. The concentration of $0.2 \mathrm{mg}$ $\mathrm{ml}^{-1}$ seawater was most effective after both 2 and $4 \mathrm{~d}$. The highest concentration $10.6 \mathrm{mg}$ $\mathrm{ml}^{-1}$ seawater) assayed of the $<10 \mathrm{~K} \mathrm{MW}$ fraction was toxic to larvae. The $10-30 \mathrm{~K} \mathrm{MW}$ and $>30 \mathrm{~K}$ MW fractions induced variable and low levels of metamorphosis. The $<10 \mathrm{~K} \mathrm{MW}$ fraction induced significantly higher levels of metamorphosis than the other fractions and FSW controls but shightly lower percent metamorphosis than UWH ( $p<0.05$, Tukey's test).

\section{Individual larval response to homogenate size fraction}

The $<10 \mathrm{~K} \mathrm{MW}$ fraction was assayed in multi-well dishes to determine if it would induce metamorphosis in individual larvae (Fig. 6). After incubation for $2 \mathrm{~d}$, $1.4 \%$ of larvae in the control (FSW only) metamorphosed while $82 \%$ of larvae $(p<0.001$, Student's $t$-test $)$ in seawater containing the $<10 \mathrm{~K} \mathrm{MW}$ fraction underwent normal metamorphosis.

\section{Separation utilizing amberlite XAD resin}

Three fractions were obtained by passing the $<10 \mathrm{~K}$ MW fraction through bond elute columns of XAD-2 and XAD-7. The water which passed through both resins was combined for assay (Thru XAD). Compounds bound to the XAD- 7 resin, assayed at a concentration of $0.2 \mathrm{mg} \mathrm{m}^{-1}$ seawater, induced $68 \%$ metamorphosis of Hydroides elegans larvae after a $2 \mathrm{~d}$ incubation (Fig. 7). The unseparated $<10 \mathrm{~K} \mathrm{MW}$ fraction, which served as a positive control, induced $72 \%$ metamorphosis after a $2 \mathrm{~d}$ incubation. There was no statistically significant difference between the FSW 


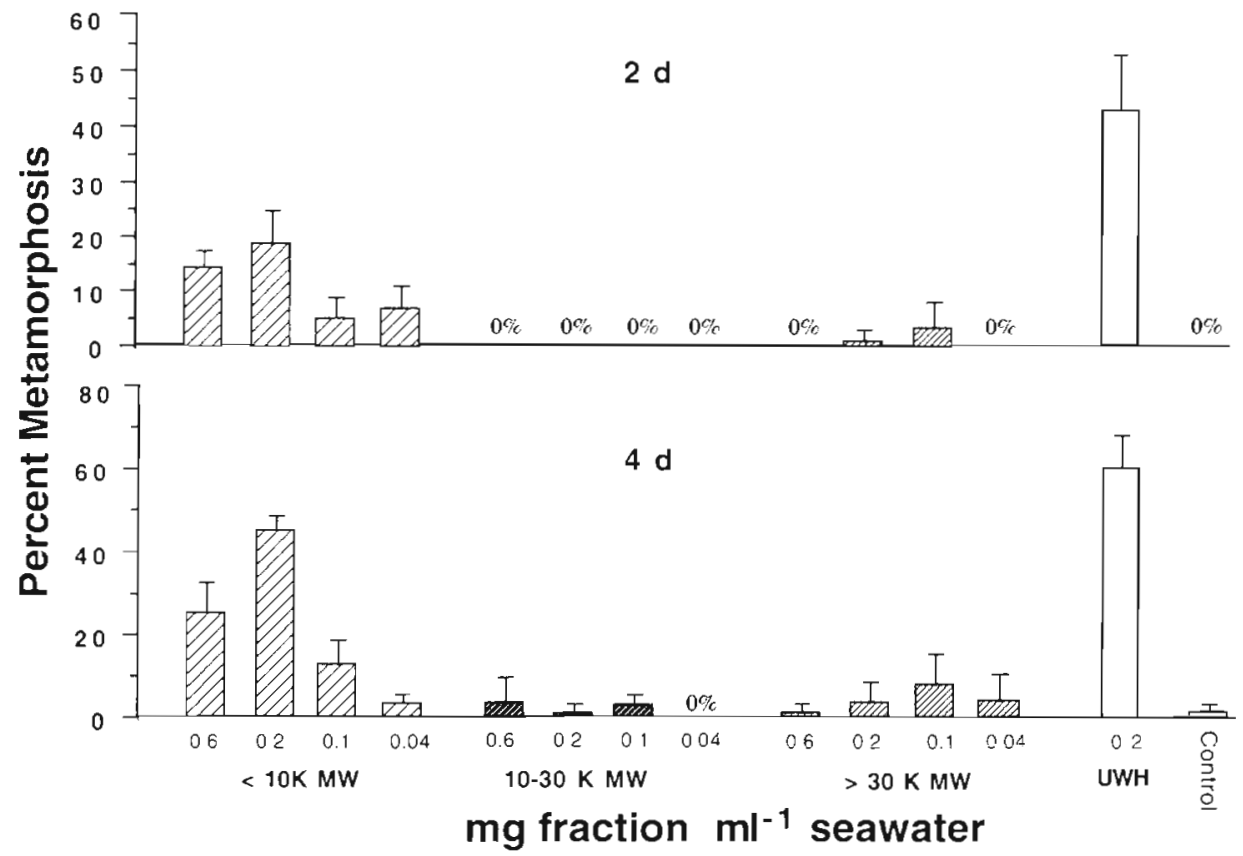

Fig. 5. Hydroides elegans. Effects of molecular weight size fractions of conspecific homogenate on percent larval metamorphosis of worms after 2 and $4 \mathrm{~d}$ incubations. Three molecular weight size fractions of the adult homogenate were assayed at 4 equivalent concentrations along with the unfractionated worm homogenate (UWH). Control is filtered seawater (FSW). Data plotted are mean \pm standard deviation of 5 replicates control and the XAD-7 residue at 0.1 and $0.04 \mathrm{mg} \mathrm{m}^{-1}$ seawater ( $p>0.05$, Tukey's test). The level of metamorphosis induced by the unfractionated extract and the XAD -7 bound compounds at $0.2 \mathrm{mg} \mathrm{m}^{-1}$ seawater were both significantly different from the control but not from each other. The XAD-2 bound compounds at $0.1 \mathrm{mg} \mathrm{ml}^{-1}$ seawater induced lower percent metamorphosis than the control while 0.2 and $0.04 \mathrm{mg} \mathrm{ml}^{-1}$ seawater induced similar percent metamorphosis which was not different from control or XAD control. The compounds Thru XAD at $0.2 \mathrm{mg} \mathrm{ml}^{-1}$ seawater induced slightly higher percent metamorphosis than 2 controls while the other 2 concentrations induced similar metamorphosis to the controls (Fig. 7).

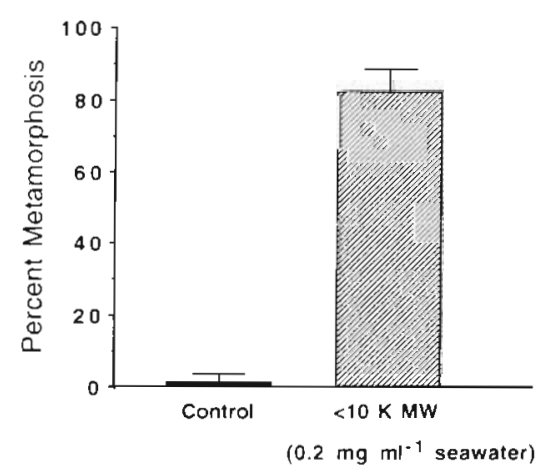

Fig. 6. Hydroides elegans. Response of individual larvae to active molecular weight fraction of conspecific homogenate in worms. Control wells contained $1 \mathrm{ml}$ of FSW alone and experiment was assayed after a $4 \mathrm{~d}$ incubation. Data plotted are mean \pm standard deviation of 3 (24-well) multi-well dishes (72 larvae per treatment)

\section{Pharmacological inducers}

Of the pharmacological inducers assayed, only IBMX induced high levels of normal metamorphosis after $4 \mathrm{~d}$ incubation (Table 1). The level of metamorphosis in response to $10^{-4} \mathrm{M} \operatorname{IBMX}(81.1 \%)$ was similar to that of $0.2 \mathrm{mg} \mathrm{ml}^{-1}$ adult homogenate $(84 \%)$ ( $\mathrm{p}>$ 0.05 , Tukey's test). IBMX at $10^{-4}$ and $10^{-5} \mathrm{M}$ induced significantly higher levels of metamorphosis than control seawater ( $p<0.05$, Tukey's test). The other compounds assayed all induced low levels of abnormal metamorphosis. Several types of abnormal metamorphosis were observed. One type was the production of tentacles and attachment to the bottom, but no tube formation; this was also observed for $\mathrm{KCl}$. A second type, involving larval production of tentacles but neither attachment nor tube formation, was observed for L-DOPA and $\mathrm{KCl}$. The third type, in which larvae became elongated but did not develop tentacles, attach, nor produce a tube, occurred when larvae were exposed to $10^{-4}$ and $10^{-5} \mathrm{M} \mathrm{GABA}$ and $10^{-4} \mathrm{M}$ ammonium chloride. Ammonia was toxic to larvae at concentrations of $10^{-2}$ and $10^{-3} \mathrm{M}$. No larvae metamorphosed in dishes containing ammonia at any of the assay concentrations.

\section{DISCUSSION}

Adult Hydroides elegans can capture conspecific larvae in feeding tentacles (Bryan, Kreider \& Qian unpubl. data). Large, competent larvae can escape 


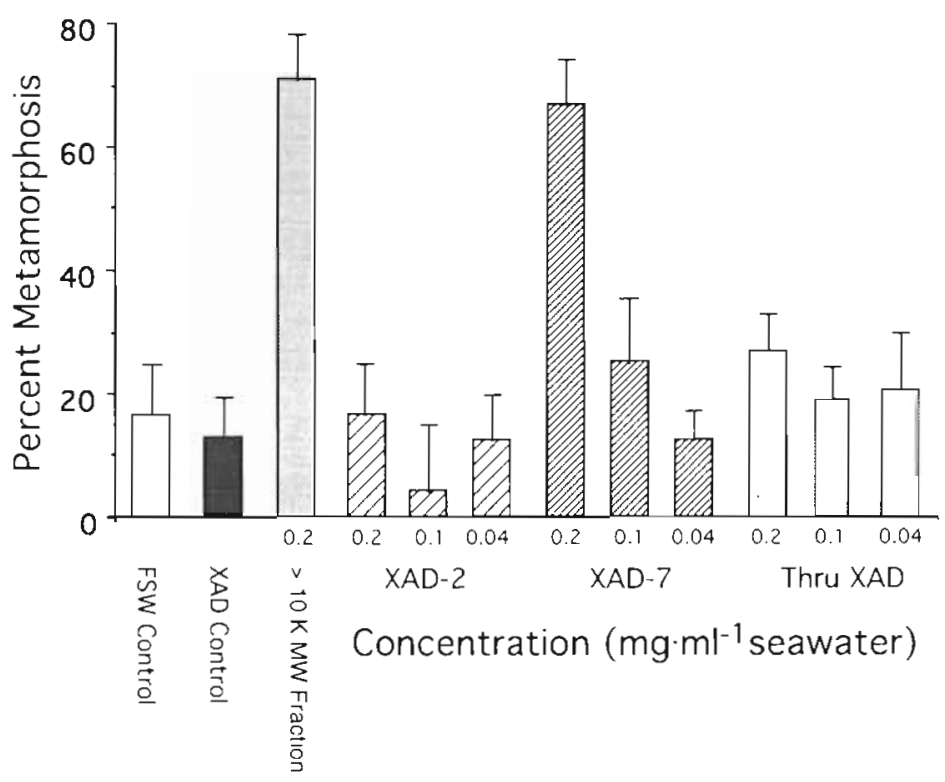

Fig. 7. Hydroides elegans. Effect of XAD fractionated compounds of conspecific homogenates of worms on percent larval metamorphosis after a $2 \mathrm{~d}$ incubation. Three additional fractions of the $<10 \mathrm{~K} \mathrm{MW}$ fraction were assayed at 3 equivalent concentrations. Data plotted are mean \pm standard deviation of 5 replicates

adult feeding tentacles while small, younger larvae are consumed (Bryan et al. unpubl. data). The capture of conspecific larvae is likely a feeding response. However, during capture, larvae are exposed to compounds from conspecifics which may induce larval metamorphosis (Toonen \& Pawlik 1996). The triggering of normal metamorphosis in $H$. elegans larvae by adult associated compounds suggests one potential pathway involved in the settlement of $H$. elegans. Bacterial films have also been found to induce metamorphosis in $H$. elegans from Hawail (Hadfield et al. 1994) and Hong Kong (P. J. Bryan unpubl. data). Moreover, the congeneric $H$. dianthus metamorphoses when exposed to bacterial films (Toonen \& Pawlik 1994). Observations in our laboratory of larvae in control dishes with filtered seawater indicate that $H$. elegans larvae would require some type of cue before undergoing metamorphosis, as larvae were observed to swim for over 2 wk when no cue was present in FSW. These observations also indicate that once larvae begin to settle, $H$. elegans larvae will crawl until beginning permanent attachment to the substratum and secretion of their tubes. Larvae may encounter a cue only momentarily then continue crawling until their attachment cement is released as ob- served in the barnacle Megabalanus rosa (A. Keiju pers. comm.). It is possible that several different metamorphic pathways exist in $H$. elegans or that 1 pathway exists but similar compounds from different sources (i.e. bacteria, conspecifics) trigger metamorphosis.

Chemical settlement inducers for marine invertebrate larvae are associated with or originate from conspecific individuals (KnightJones 1953, Seki \& Kan-no 1981, Highsmith 1982, Burke 1984, Pawlik 1986, Pearce \& Scheibling 1990, Slattery 1992, Toonen \& Pawlik 1996), microbial films (Cameron \& Hinegardner 1974, Kirchman et al. 1982, Maki et al. 1989, Bonar et al. 1990, Pearce \& Scheibling 1991, Hadfield et al. 1994, Toonen \& Pawlik 1994), and food items (Barnes \& Gonor 1973, Morse et al. 1979, Hadfield \& Pennington 1990, Todd et al. 1991). Specific compounds isolated from these sources are peptides (Burke 1984, Zimmerfaust \& Tamburri 1994) and free fatty acids (Pawlik 1986, Kitamura et al. 1993). However, due to the paucity of natural compounds isolated and identified which induce metamorphosis in marine invertebrates, no generalizations concerning types of compounds or metamorphic pathways can be made. Moreover, the fact that larvae of some species of benthic marine invertebrates will metamorphose in response to a variety of natural and artificial cues (Pennington \& Hadfield 1989, Pearce \& Scheibling 1991, Pechenik et

Table 1 Hydroides elegans. Induction of metamorphosis by pharmacological compounds. Values are presented as percent of total larvae metamorphosed from 5 replicate dishes containing approximately 20 larvae each. Dishes contained filtered seawater ( $35 \mathrm{ppt}$ ) and were incubated at $24^{\circ} \mathrm{C}$ for $4 \mathrm{~d}$ on a $15: 9 \mathrm{~h}$ light:dark photoperiod. Standard deviations are presented in parentheses. Normal metamorphosis is designated $(n)$, while abnormal metamorphosis types are denoted by the following symbols: (@) attached with tentacles but no tube, (\#) not attached with tentacles and no tube, (*) not attached, no tentacles or tube. In control (FSW), $3 \%$ larvae metamorphosed after 4 d incubation

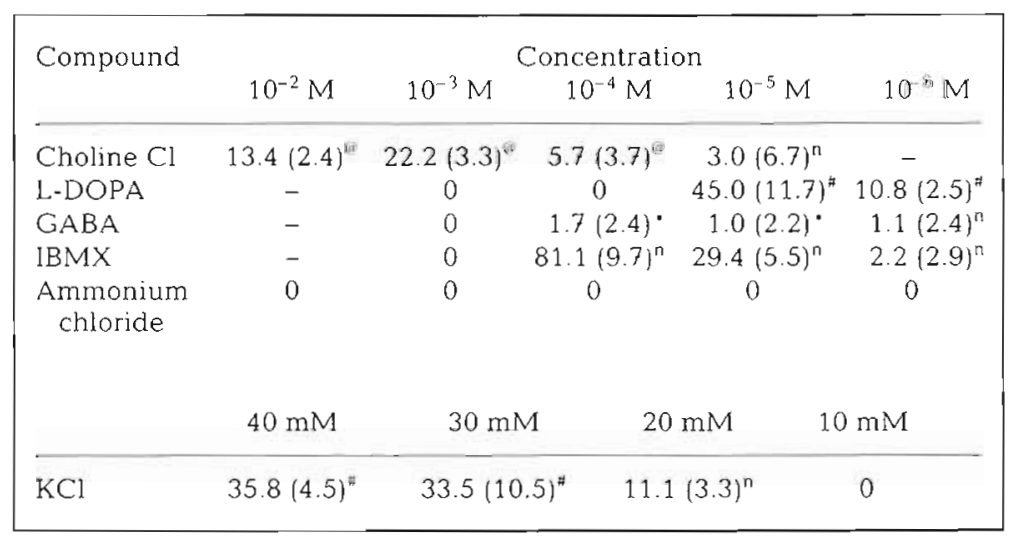


al. 1995) supports the theory that several pathways may exist. Only through studies which attempt to characterize natural settlement inducers of a wide variety of marine invertebrates will clear conclusions be drawn concerning the conservation of similar pathways through evolutionary time.

We found that high densities of larvae induced low levels of metamorphosis, indicating that gregariousness may be a result of larval interactions in addition to larval/adult interactions. It is possible that larvae release compounds into the water which stimulate their conspecifics (Yule \& Walker 1984, Clare et al. 1994). Connaughton et al. (1994) demonstrated that larvae of Hydroides dianthus, in high concentrations, released compounds into the water which decreased feeding of larval weakfish. In addition to water-soluble compounds, the glue of conspecifics may contain compounds which can induce others to metamorphose (Jensen \& Morse 1990). An dilernative is that the high densities of larvae increased bacterial growth in these containers and the bacterial film induced larval metamorphosis. Nonetheless, this evidence suggests that low densities of larvae should be used in laboratory assay.

In this study, we found that the adult homogenate with a molecular weight less than $10000 \mathrm{MW}$ was responsible for metamorphic induction. Active compound(s) within this fraction were absorbed to an amberlite XAD-7 resin. Since XAD-7 resins are utilized to isolate and purify peptides (Quinn 1988), there is a likelihood that the inductive substance may be a peptide or a compound of similar size and polarity. Ongoing isolation and structural analysis will reveal the true nature of the inductive substance. This compound(s) may be released into the water from living or recently dead Hydroides elegans. This finding supports the theory that larvae can be induced by conspecifics to recruit into areas near established beds of conspecifics. The potent triggering of metamorphosis is the most convincing evidence of the role of the aqueous-soluble compounds from conspecifics. An alternative possibility is that marine bacteria flourish in the presence of compounds (potentially nutritive) from adult $H$. elegans. These bacteria may produce compounds which attract larvae to settle and metamorphose. In the present study, the possibility of bacterially produced metabolites being responsible for the observed activity remains uncertain. Nonetheless, under natural conditions both conspecific related compounds and bacteria (Hadfield et al. 1994) likely affect larval site selection and metamorphic induction. Toonen \& Pawlik (1996) demonstrated that larvae of $H$. dianthus metamorphose preferentially on bacterial filmed substrates over clean substrates. Moreover, the level of metamorphosis in $H$. dianthus larvae increases when incubated with water-soluble compounds originating from conspecific adults (Toonen \& Pawlik 1996). The ability of conspecific associated compounds to induce metamorphosis in both $H$. dianthus (Toonen \& Pawlik 1996) and $H$. elegans (this study) suggests that many similarities may exist between these 2 species

Potassium ions have been used effectively to induce metamorphosis in a variety of invertebrate larvae (reviewed by Pearce \& Scheibling 1994). In this study, potassium chloride was used to elevate the $\left[\mathrm{K}^{+}\right]$in the seawater. The abnormal metamorphosis observed in larvae of Hydroides elegans to elevated $\mathrm{KCl}$ indicates these pathways may not be active. Gamma-aminobutyric acid (GABA) is an inhibitory neurotransmitter and induces hyperpolarization of post-synaptic membranes by means of an increase in membrane permeability to chloride ions. GABA may be involved in the metamorphic process of some invertebrate larvae (Morse 1990), however, GABA did not induce larval metamorphosis of $H$. elegans. Choline is the precursor of the neurotransmitter acetocholine and induces larval metamor. phosis of several invertebrate larvae (Hirata \& Hadfield 1986, Pawlik 1990). Again, choline did not effect metamorphosis of $H$. elegans larvae. L-DOPA is a tyrosine derivative and affects settlement of oyster larvae (Bonar et al. 1990, Coon et al. 1990a) and metamorphosis of the polychaete Phragmatopoma lapidosa (Jensen \& Morse 1990; however see Pawlik 1990). L-DOPA did not induce normal metamorphosis in $H$. elegans larvae. Isobutyl methylxanthine (IBMX) is a phosphodiesterase inhibitor which causes increases in c-AMP levels. IBMX induced normal larval metamorphosis of the polychaete P. lapidosa (Jensen \& Morse 1990, Pawlik 1990) and the barnacle Balanus amphitrite (Clare et al. 1994). IBMX was the only artificial inducer that induced significant levels of normal metamorphosis of $H$. elegans in this study. This compound can be used to study metamorphic competence and can be involved in future studies of signaling pathways in $H$. elegans.

Acknowledgements. The authors thank Drs M. Hadfield and E. Holm for sharing their knowledge on larval culture of Hydroides elegans, Dr D. Rittschof for his comments on both research protocol and editing, 3 anonymous reviewers for valuable comments on the manuscript, and V. Whale Limited of Hong Kong for allowing us access to their fish farm. This research was supported by 2 RGC grants (HKUST 574/95M and HKUST651/96M).

\section{LITERATURE CITED}

Baloun AJ, Morse DE (1984) Ionic control of settlement and metamorphosis in larval Haliotis rufescens (Gastropoda). Biol Bull Mar Biol Lab, Woods Hole 167:124-138

Barnes JR, Gonor JJ (1973) The larval settling response of the lined chiton Tonicella lineata. Mar Biol 20:259-264

Bartlett MS (1937) Some examples of statistical methods of 
research in agriculture and applied biology. Suppl J Royal Soc 4:137-170

Bonar DB, Coon SL, Walch M, Weiner RM, Fitt W (1990) Control of oyster settlement and metamorphosis by endogenous and exogenous chemical cues. Bull Mar Sci 46: $484-498$

Burke RD (1984) Pheromonal control of metamorphosis in the Pacific sand dollar, Dendraster excentricus. Science 225: $442-443$

Cameron RA, Hinegardner R (1974) Initiation of metamorphosis in laboratory cultured sea urchins. Biol Bull Mar Biol Lab. Woods Hole 146:335-342

Clare A.S, Freet RK, McClary M (1994) On the antennular secretion of the cyprid of Balanus amphitrite amphitrite. and its role as a settlement pheromone. J Mar Biol Ass UK $74: 243-250$

Connaughton VP, Schuur A, Targett NM, Epifanio CE (1994) Chemical suppression of feeding in larvae weakfish (Cynoscion regalis) by trochophores of the serpulid polychaete Hydroides dianthus. J Chem Ecol 20:1763-1771

Coon SL, Bonar DB, Weiner RM (1985) Induction of settlement and metamorphosis of the Pacific oyster, Crassostrea gigas (Thunberg), by L-DOPA and catecholamines. J Exp Mar Biol Ecol 94:211-221

Coon SL, Fitt WK, Bonar DB (1990a) Competence and delay of metamorphosis in the Pacific oyster Crassostrea gigas. Mar Biol 106:379-387

Coon SL, Walch M, Fitt WK, Weiner RM, Bonar DB (1990b) Ammonia induces settlement behavior in oyster larvae. Biol Bull 179:297-303

Fitt WK, Coon SL, Walch M, Weiner RM, Colwell RR, Bonar DB (1990) Settlement behavior and metamorphosis of oyster larvae (Crassostrea gigas) in response to bacterial supernatants. Mar Biol 106:379-394

Hadfield MG, Pennington JT (1990) Nature of the metamorphic signal and its internal transduction in larvae of the nudibranch Phestilla sibogae. Bull Mar Sci 46:455-464

Hadfield MG, Unabia CC, Smith CM, Michael TM (1994) Settlement preferences of the ubiquitous fouler Hydroides elegans. In: Thompson MF, Nagabhushanam R, Sarojini R, Fingerman $M$ (eds) Recent developments in biofouling control. Balkema, Rotterdam, p 65-74

Highsmith RC (1982) Induced settlement and metamorphosis of sand dollar (Dendraster excentricus) larvae in predatorfree sites: adult sand dollar beds. Ecology 63:329-337

Hirata KY, Hadfield MG (1986) The role of choline in metamorphic induction of Phestilla (Gastropoda: Nudibranchia). Comp Biochem Physiol 84C:15-21

Jensen RA, Morse DE (1990) Chemically induced metamorphosis of polychaete larvae in both the laboratory and the ocean environment. J Chem Ecol 16:911-930

Kirchman D, Graham S, Reish D, Mitchell R (1982) Bacteria induce settlement and metamorphosis of Janua (Dexiospira) brasiliensis Grube (Polychaeta: Spirorbidae). J Exp Mar Biol Ecol 56:153-163

Kitamura H, Kitahara S, Koh HB (1993) The induction of larval settlement and metamorphosis of two sea urchins, Pseudocentrotus depressus and Anthocidaris crassispina, by free fatty acids extracted from the coralline red alga Corallina pilulifera. Mar Biol 115:387-392

Knight-Jones EW (1953) Laboratory experiments on gregariousness during settling in Balanus balanoides and other barnacles. J Exp Biol 30:584-599

Maki JS, Rittschof D, Schmidt AR, Snyder AG, Mitchell R (1989) Factors controlling attachment of bryozoan larvae: a comparison of bacterial films and unfilmed surfaces. Biol Bull 177:295-302
Morse ANC, Morse DE (1984) Recruitment and metamorphosis of Haliotis larvae induced by molecules uniquely available at the surfaces of crustose red algae. J Exp Mar Biol Ecol 75:191-215

Morse DE (1990) Recent progress in larval settlement and metamorphosis: closing the gaps between molecular biology and ecology. Bull Mar Sci 46:465-483

Morse DE, Hooker N, Duncan H, Jensen L (1979) $\gamma$-Aminobutyric acid, a neurotransmitter, induces planktonic abalone larvae to settle and begin metamorphosis. Science 204 : $407-410$

Pawlik JR (1986) Chemical induction of larval settlement and metamorphosis in the reef-building tube worm Phragmatopoma callfornica (Sabellaridae: Polychaeta). Mar Biol 91:59-68

Pawlik JR (1990) Natural and artificial induction of metamorphosis of Phragmatopoma lapidosa californica (Polychaeta: Sabellariidae), with a critical look at the effects of bioactive compounds on marine invertebrate larvae. Bull Mar Sci 46:512-536

Pawlik JR (1992) Chemical ecology of the settlement of benthic marine invertebrates. Oceanogr Mar Biol Ann Rev 30 : $273-335$

Pearce CM, Scheibling RE (1990) Induction of settlement and metamorphosis in the sand dollar Echinarachnius parma: evidence for an adult-associated factor. Mar Biol 107. $363-369$

Pearce CM, Scheibling RE (1991) Effect of macroalgae, microbial films, and conspecifics on the induction of metamorphosis of the green sea urchin Strongylocentrotus droebachiensis (Müller). J Exp Mar Biol Ecol 147:147-162

Pearce CM. Scheibling RE (1994) Induction of metamorphosis of larval echinoids (Strongylocentrotus droebachiensis and Echinarachnius parma) by potassium chloride ( $\mathrm{KCl}$ ). Invertebr Reprod Dev 26:213-220

Pechenik JA, Hadfield MG, Eyster LS (1995) Assessing whether larvae of the opisthobranch gastropod Phestilla sibogae Bergh become responsive to three chemical cues at the same age. J Exp Mar Biol Ecol 191:1-17

Pechenik JA, Heyman WD (1987) Using KCl to determine size at competence for larvae of the marine gastropod Crepidula fornicata (L.). J Exp Mar Biol Ecol 112:27-38

Pennington JT, Hadfield MG (1989) Larvae of a nudibranch mollusc (Phestilla sibogae) metamorphose when exposed to common organic solvents. Biol Bull 177:350-355

Quinn RJ (1988) Chemistry of aqueous marine extracts: isolation techniques. In: Scheuer PJ (ed) Bioorganic marine chemistry, Vol 2. Springer-Verlag, Berlin, p 1-41

Rittschof D, Maki J, Mitchell R, Costlow MD (1986) Ion and neuropharmacological studies of barnacle settlement. Neth J Sea Res 20:269-275

Rodriguez SR, Ojeda FP, Inestrosa NC (1993) Settlement of benthic marine invertebrates. Mar Ecol Prog Ser 97 . $193-207$

Scheltema RS, Williams IP, Shaw MA, Loudon C (1981) Gregarious settlement by the larvae of Hydroides dianthus (Polychaeta: Serpulidae). Mar Ecol Prog Ser 5:69-74

Seki T, Kan-no H (1981) Induced settlement of the Japanese abalone, Haliotis discus hannai, veliger by the mucus of the juvenile and adult abalones. Bull Tohoku Reg Fish Res Lab 43:29-36

Slattery M (1992) Larval settlement and juvenile survival in the red abalone (Haliotis rufescens): an examination of inductive cues and substrate selection. Aquaculture 102: $143-153$

Todd CD, Bentley MG, Havenhand JN (1991) Larval metamorphosis of the opisthobranch mollusc Adalaria proxima 
(Gastropoda: Nudibranchia): the effects of choline and elevated potassium ion concentration. J Mar Biol Ass UK $71: 53-72$

Toonen RJ, Pawlik JR (1994) Foundations of gregariousness. Nature 370:511-512

Toonen RJ, Pawlik JR (1996) Seltlement of the tube worm Hydroides dianthus (Polychaeta: Serpulidae): cues for gregarious settlement. Mar Biol (in press)

Weiner RM, Segall AM, Colwell RR (1985) Characterization of a marine bacterium associated with Crassostrea virginica

This article was submitted to the editor (the eastern oyster). Appl Environ Microbiol 50:83-90

Wisely B (1958) The development and settling of a serpulid worm, Hydroides norvigica Gunnerus (Polychaeta). Aust J Mar Freshwat Res 9:351-361

Yule AB, Walker G (1984) The temporary adhesion of barnacle cyprids: effects of some differing surface characteristics. J Mar Biol Ass UK 64:429-439

Zimmerfaust RK, Tamburri MN (1994) Chemical identity and ecological implications of a waterborne, larval settlement cue. Limnol Oceanogr 39:1075-1087

Manuscript first received: March 26, 1996

Revised version accepted: September 17, 1996 